\title{
«МОЛОТОВСКИЙ КОКТЕЙЛЬ» ОБРАЗЦА 1943 Г. В БОРЬБЕ ЗА ПОВЫШЕНИЕ ИДЕЙНО-ХУДОЖЕСТВЕННОГО УРОВНЯ СОВЕТСКОЙ ЛИТЕРАТУРЫ
}

\author{
М.Г. Нечаев, \\ дочент, канд. ист. наук, \\ Пермский национальный исследовательский \\ политехнический университет \\ mgn4@mail.ru
}

\begin{abstract}
Аннотация. Тотальный контроль за художественным творчеством в рамках социалистического реализма был обычной практикой начиная со второй половины 30-х гг. ХХ в. в СССР. Концентрация писателей и поэтов в столичных регионах давала возможность это делать на уровне центральной партийной власти. Однако в годы войны местные партийные и советские власти оказались не способны контролировать «творческую свободу» мастеров художественного слова, эвакуированных в глубокий тыл, и ярким примером этому стал неожиданный «литературный бум» в Молотовской (Пермской) области. На основе новых материалов реконструируются события, связанные с постановлением ЦК ВКП(б) «О работе Молотовского областного издательства» от 19 марта 1943 г., ставшие началом массовой идеологической кампании против художественной интеллигенции в послевоенный период.

Ключевые слова: Союз писателей; литфонд; Молотовское областное издательство; советская литература; ЦК ВКП(б); управление пропаганды и агитации; литературно-художественный альманах «Прикамье»; Молотовский обком партии; эвакуация.
\end{abstract}

\section{MOLOTOV COCKTAIL OF 1943 IN THE STRUGGLE TO RAISE THE IDEOLOGICAL AND ARTISTIC LEVEL OF SOVIET LITERATURE}

\author{
M.G. Nechaev, \\ associate Professor, PhD. east. sciences \\ Perm national University research Polytechnic University \\ mgn4@mail.ru
}

Summary. Total control of artistic creativity within the framework of socialist realism has been a common practice since the second half of the $30 \mathrm{~s}$ of the 
twentieth century in the USSR. The concentration of writers and poets in the capital's regions allowed this to be done at the levels of the Central party power. However, during the war, the local party and Soviet authorities were unable to control the «creative freedom «of the masters of the artistic word, who were evacuated to the deep rear.a striking example of this was the unexpected» literary boom «in the Molotov (Perm) region. This article uses new materials to reconstruct the events related to the resolution of the Central Committee of the CPSU (b) «on the work of the Molotov regional publishing house» of March 19, 1943, which became the beginning of a mass ideological campaign against the artistic intelligentsia in the post-war period.

Keyword: Union of writers; litfond; Molotov regional publishing house; Soviet literature; Central Committee of the CPSU (b); propaganda and agitation Department; literary and artistic almanac «Prikamye»; Molotov regional party Committee; evacuation.

Постановление оргбюро ЦК ВКП(б) «О журналах “Звезда" и “Ленинград”» [26, с. 587-591] от 14 августа 1946 г. стало началом публичной широкомасштабной кампании уничижительного осуждения и шельмования писателей, поэтов, композиторов и других деятелей культуры в Советском Союзе. Вплоть до 1948 г. продолжалось публичное обсуждение «порочных, надуманных» произведений искусств, культивирующих «упаднические, ущербные настроения», а также являющихся «пошлыми», «малохудожественными» и «идейно порочными» [14, с. 559-565]. Эхо этой кампании прокатилось по всей стране, в том числе и в Молотовской (Пермской) области, где местная печать разоблачала М. Зощенко и А. Ахматову [17, с. 188-195].

Однако именно в Молотовской (Пермской) области в годы войны, в 1943 г., произошли события, ставшие прологом обострившейся будущей ожесточенной трехлетней борьбы за повышение идейно-художественного уровня советской литературы. В апреле 1943 г. на страницах журнала ЦК ВКП(б) «Партийное строительство» были опубликованы две статьи, которые объединяло только то, что речь шла о Молотовской (Пермской) области.

В передовой статье первого секретаря Молотовского обкома ВКП(б) Николая Ивановича Гусарова «Руководить - это значит предвидеть» [13, с. 7-12] говорилось об экономических успехах области, в которой за годы войны был налажен выпуск 800 новых видов продукции, необходимой для фронта. На территории Пермского края (Молотовской области) было произведено за годы вой- 
ны более 90 \% всех порохов. Соликамский магниевый завод оказался единственным в стране производителем товарного магния. Усть-Боровской сользавод после захвата немецкими войсками Новгородской области и районов вокруг озера Баскунчак на некоторое время стал единственным источником солеварения для страны. В связи с потерей Донбасса роль Кизеловского бассейна, дающего коксующийся уголь, чрезвычайно возросла. Мотовилихинский завод дал фронту 48600 артиллерийских систем - каждую четвертую, произведенную тогда в стране. Для боевых самолетов, выпущенных в те годы индустрией СССР числом 136,8 тысячи единиц, пермские моторостроители сделали 31 тысячу авиационных моторов, или $22 \%$ от их общего количества. Завод им. Ф.Э. Дзержинского освоил производство боеприпасов и дал более $30 \%$ взрывателей к снарядам, произведенным всей промышленностью страны во время войны. Завод им М.И. Калинина (в годы войны завод № 33, а в наше время ОАО «Пермское агрегатное объединение "Инкар" - ОАО “Стар"») за годы войны выпустил 1 миллион 107 тысяч карбюраторов. Лысьвенский металлургический завод - единственное предприятие, где выпускались все стальные каски («Шлем стальной образца 1940 г.», или СШ-40) периода Великой Отечественной войны, а Пермский телефонный завод стал единственным поставщиком полевых телефонных аппаратов для фронта [19, с. 85-88].

Н.И. Гусаров в своей статье проводил мысль, что партия в ответе за все что происходит, в том числе должна нести ответственность и за «приводные ремни» - комсомол, профсоюз и т.д. Это было очень актуально, так как именно в данный момент вышло постановление ЦК ВЛКСМ «О крупных недостатках в работе Молотовского обкома ВЛКСМ» [15]. Он делает вывод «Партийный руководитель должен быть прежде всего мастером политической работы, организатором и воспитателем тысяч людей. <..> Мы должны еще более укрепить организованность и дисциплину в тылу, усилить мобилизацию всех резервов для дела победы над врагом, еще выше поднять уровень партийного руководства» [13, с. 12].

В рубрике «На текущие темы» в журнале напечатали безымянную заметку «Областное издательство», в которой излагалось краткое содержание постановления ЦК ВКП(б) «О работе Молотовского областного издательства», принятое на заседании Секре- 
тариата ЦК ВКП(б) 19 марта 1943 г. Это было первое в истории ЦК ВКП(б) постановление, посвященное работе «местного» (регионального) издательства. В преамбуле определялись основные компетенции и обязанности «местных издательств»: «Выпускать литературу, помогающую областным организациям успешно решать политические и хозяйственные задачи, встающие в ходе войны. Неотложным нуждам местной промышленности и сельского хозяйства, опыту лучших промышленных предприятий и колхозов, использованию местных ресурсов, опыту партийно-политической работы - вот чему должны в первую очередь посвящаться книжки областных издательств» $[21$, с. 23]. Но самый главный тезис был о том, что «издательское дело требует руководства» и это «серьезный участок идеологической работы», поэтому «пониженная требовательность к авторам, небрежность в редактировании должны встречать самое суровое осуждение со стороны партийных организаций» [21, с. 23].

С одной стороны, в постановлении говорилось о том, что «Молотовское издательство разбазаривает бумагу на выпуск бессодержательных и никому не нужных книг» [21, с. 23]. С другой стороны, речь шла о «грубых политических ошибках», допущенных издательством [21, с. 24]. А всё это «явилось следствием отсутствия руководства издательством со стороны Молотовского обкома ВКП(б)» [21, с. 24]. ЦК ВКП(б) постановила: 1) освободить от должности секретаря Молотовского обкома ВКП(б) по пропаганде и агитации «товарища Жукова, как не справившегося с работой»; 2) обязали первого секретаря Молотовского обкома ВКП(б) обсудить на заседании бюро обкома отчет о работе издательства и «принять меры к устранению указанных в настоящем решении недостатков»; 3) «категорически запрещалось» выпускать литературу Молотовскому издательству без утверждения тематического плана бюром обкома ВКП(б) и Управлением пропаганды и агитации ЦК ВКП(б), а отдел пропаганды и агитации Молотовского обкома обязан был «обеспечить тщательный предварительный просмотр рукописей всей издаваемой литературы»; 4) запрещалось всем «местным издательствам» выпускать литературу без утверждений тематических планов Управлением пропаганды и агитации ЦК ВКП(б); 5) постановление рассылалось во все обкомы, крайкомы и ЦК компартий союзных республик. 
Почему именно Молотовское издательство стало объектом такого пристального внимания со стороны секретариата и Управления пропаганды и агитации ЦК ВКП(б)? Неужели сотрудники Молотовского издательства совершили такие серьезные «политические ошибки» и за полтора года войны выпустили больше, чем остальные «бессодержательных и никому не нужных книг»?

В годы войны произошли качественные изменения в культурной жизни Пермского края (Молотовской области) и это связано прежде всего с эвакуацией известных столичных культурных учреждений, а также целым рядом известных писателей, композиторов, артистов и художников. Несмотря на трагические обстоятельства, в результате которых это стало возможно, сложились абсолютно уникальные условия для оживления провинциальной культурной жизни.

До 1940 г. литературной столицей Урала был Свердловск, где было открыто Уральское отделение Союза советских писателей. Там же издавался ежемесячный журнал «Штурм», а с 1938 г. «Уральский современник». Пермская область указом Президиума Верховного Совета СССР от 3 октября 1938 г. была выделена из Свердловской области с центром в городе Перми. Еще до появления Пермской области как самостоятельной административно-территориальной единицы в Перми уже жили литераторы: А.Н. Спешилов, Е.Ф. Трутнева, Б.Н. Михайлов, В.Л. Занадворов и др. [1, с. 125]. В основном они публиковались в Москве, Ленинграде, Казани, Свердловске. В Свердловске работало всеуральское издательство, выходил ежемесячный журнал «Штурм», с 1938 г. - альманах «Уральский современник», кроме того, в городе находилось уральское отделение Союза советских писателей, в которое входило четыре пермяка: Б. Михайлов, А. Спешилов, В. Каменский и Г. Коновалов [1, с. 125]. Поэт Борис Михайлов писал в газете «Звезда»: «Читатели Перми не знают своих писателей» [1, с. 125].

26 августа 1939 г. бюро Пермского обкома ВКП(б) рассмотрело вопросы «Об организации областного издательства» и «Об издании литературно-художественного альманаха» $[22$, ф. 105, оп. 1 , д. 31, л. 184]. По первому вопросу было принято решение: «Организовать Пермское областное издательство для издания политической, научной и художественной литературы», а по второму: «Просить ЦК ВКП(б) разрешить издание литературно-художественного альманаха» [22, ф. 105, оп. 1, д. 31, л. 184]. 
Издательство занимало бывшее складское помещение с низким потолком и земляным полом. В штате издательства было всего три человека: директор, редактор и бухгалтер [36, с. 142]. С начала 1941 г. издательство получило помещение получше, и в штат приняли еще одного редактора, а также корректора, счетовода и завхоза [36, с. 142].

23 февраля 1940 г. было утверждено Молотовское отделение Союза советских писателей [16, с. 489]. А.Н. Спешилов был избран ответственным секретарем областной писательской организации, а Борис Михайлов - уполномоченным Литфонда [36, с. 147]. До войны в Пермском крае (Молотовской области) было всего пять членов и кандидатов в Союз советских писателей - В. Каменский, Б. Михайлов, А Спешилов, Н. Попов, С. Караваев и восемь человек литературного актива.

А.Н. Спешилову как редактору редакции художественной литературы областного издательства поручили руководить группой «литературного актива», которые проходили «теоретическую подготовку» - им проводили занятия преподаватели университета и пединститута Боголюбов, Будрин, Ефимов, Ожегова [36, с. 143]. По воспоминаниям А.Н. Спешилова, занимались «...Баталов, Бычков, Занадворов, Александр Каменский, Коновалов, Матросов, Трайнин, Трутнева, Якубов. Приезжали из Кудымкара поэты Караваев и Попов, бывали на наших занятиях Василий Васильевич Каменский и известный уральский собиратель устного народного творчества жизнерадостный, желанный наш гость Валентин Николаевич Серебренников (Аргентов)» [36, с. 143].

Если в 1939 г. в Перми (Молотове) увидело свет всего три книги (Жукова А. «Жизнь крестьян прежде и теперь»; Кондакова А. «Промышленность и транспорт Пермской области»; Гришина А. «Праздник счастья») и выглядели они крайне неказисто, были отпечатаны на газетной бумаге, плохо оформлены, иллюстрации отретушированы грубо [1, с. 128], то в 1940 г. предполагалось издать 45 книг, но вышло всего 26 [1, с. 128-129]. 4 декабря в 1940 г. вышел первый номер литературно-художественного альманаха «Прикамье» - органа Пермской писательской организации. В нем были опубликованы произведения В. Каменского, Б. Михайлова, Е. Трутневой, А. Бычкова [20, с. 20-21]. 
В начале Великой Отечественной войны большая часть литературного актива Молотовской области была призвана на фронт: Бычков, Занадворов, Баталов, Кайгородов, Караваев, Попов. В Свердловском отделении Союза писателей осталось всего 15 человек, в Молотовском - шесть [35, с. 308]. Мобилизованы были директор Молотовского издательства Катаев, секретарь парторганизации Титов, бухгалтер Рудометов, заведующий хозяйством Зеленин [36, с. 156]. Вместо Катаева директором издательства назначили Макарова [36, с. 157]. 20 февраля 1942 г. Объединение государственных издательств при СНК РСФСР (ОГИЗ) предложило А.Н. Спешилову принять дела издательства [36, с. 157].

Одновременно с этим в восточные районы страны началась массовая эвакуация писателей. В Свердловск прибыли: А. Барто, Ю.Верховский, Ф. Гладков, Л. Гроссман, Л. Кассиль, А. Караваева, Е. Пермяк, М. Шагинян, А. Коц и др. [35, с. 308]. В результате Свердловское отделение Союза писателей увеличилось до 64 человек [35, с. 308]. На этой основе в Свердловске был создан Уральский литературный центр, который возглавили известные всей стране писатели П. Бажов, А. Караваева и Е. Пермяк [35, с. 308].

В Чкалов (Оренбург) был эвакуирован поэт А. Фатьянов, прозаики В. Альбертон, О. Гольдес, драматург А. Цикорьков, очеркист Х. Левина, молодые писатели А. Коваленков, Е. Рысс, В. Герасимова. Это позволило в 1942 г. создать областное отделение Союза писателей [35, с. 309].

В Уфе творческую деятельность продолжили П. Тычина, М. Рыльский, П. Панч, А. Корнейчук, Н. Рыбак, В. Сосюра, И. Кочерга. В Ижевске нашли пристанище Н. Ляшко, А. Карцев, Я. Годин, Д. Каневский и другие. Значительно выросла количественно и Челябинская писательская организация, возобновившая свою деятельность с сентября 1941 г. [35, с. 309].

Одни из первых из Москвы в Молотов (Пермь) 25 июля 1941 г. приехали Брики - Осип Максимович Брик (ближайший друг В. Маяковского) со своей женой Е.Г. Соколовой и Лиля Юрьевна Брик - первая жена Осипа Максимовича, муза В. Маяковского, которая вновь вышла замуж за московского литераторамаяковеда Василия Абгаровича Катаняна [10].

К 12-й годовщине гибели Владимира Маяковского (14 апреля 1930 г.) в городе Молотове (Перми) прошла целая серия мероприя- 
тий, посвященных памяти поэта. 15 сентября 1941 г. была подписана в печать и издано пятитысячным тиражом книга, составленная В.А. Катаняном, - Маяковский В. «Лозунги-рифмы» [18]. Л.Ю. Брик подготовила к печати рассказ-воспоминания «Щен», который был написан еще в самом начале 1936 г. Этот рассказ с рисунками Л.Ю. Брик вышел из печати в апреле 1942 г. [7].

В г. Молотов (Пермь) эвакуировалась большая группа советских писателей: Н.В. Гернет, Я.Л. Горев, В.А. Каверин, М.Э. Козаков, Л.М. Козелова, И.В. Луковский, И.С. Соколов-Микитов, А.А. Первенцев, Е.Г. Полонская, С.Е. Розенфельд, Н.Я. Рыкова, М.Л. Слонимский, Ю.Н. Тынянов и Л.Н. Тынянова, А.А. Френкель (д'Актиль), Н.Ф. Фридлянд, А.П. Штейн и др. [23, с. 95] В г. Осу вместе со своей семьей приезжает выдающийся русский писатель и автор популярных детских произведений Виталий Валентинович Бианки [5]. Только из Москвы и Ленинграда эвакуировались 43 члена Союза советских писателей. А всего на учете в Молотовском отделении Союза советских писателей теперь состоял 71 человек [11, ф.р. 1188 , оп. 1; д. 1, л. 1; ф.р. 1588, оп. 1; д. 599; л. 6].

Приезжие писатели селились, главным образом, в номерах гостиницы, которую все звали - «семиэтажка» (ныне гостиница «Центральная»). При писательской группе был организован Литфонд, с помощью которого писатели обеспечивались ссудами и решались их бытовые проблемы. Например, для писателей ежедневно готовили бесплатный обед, они могли получить семена огородных растений и им выдавали вино [6, с. 34-35]. Для писательских детей устроили детский лагерь в деревне Черной на 200 мест в двух часах езды от Перми. Лагерь состоял на особом снабжении, дети были обеспечены питанием, кровом, врачебный надзором, школьным образованием. 150 мамам с детьми предоставляли места в домах колхозников, при этом выделялись «дрова и продовольствие» [11, ф. р-1206, оп. 1, д. 16, л. 102].

Приезд ведущих отечественных писателей совершенно изменил литературную жизнь Прикамья. Из литературного захолустья Пермь превращается в один из ведущих литературных центров. Если в целом в стране тираж книг в 1943 г., по сравнению с 1940 г., сократился более чем в два раза [1, с. 132], то доля восточных книгоиздательских центров возросла по тиражу книг с 6 до $13 \%$, а по числу названий - с 34 до $54 \%$ [1, с. 132]. И заметную 
часть этого прироста давал Урал, в том числе Молотовская (Пермская) область.

В эвакуации творческая работа не прекращалась. Смертельно больной Ю.Н. Тынянов писал исторические рассказы и очерки, а также продолжал работать над третьей частью своего последнего романа «Пушкин». Здесь был написан его последний рассказ «Гражданин Очер» В литературно-художественном сборнике (альманахе) «Прикамье» были опубликованы два его рассказа: «Генерал Дорохов» [29, с. 3-10] и «Красная шапка» [29, с. 13-14]. Умер Ю.Н. Тынянов в декабре 1943 г., вернувшись из эвакуации в Москву.

Выдающийся советский писатель В.А. Каверин писал в Перми (Молотове) рассказы о защитниках Ленинграда и в то же время в литературно-художественном сборнике (альманахе) «Прикамье» были опубликованы главы одного из самых знаменитых его романов - «Два капитана» [29, с. 19-37].

В Перми (Молотове) вышли в свет пьеса «Девочки» и повесть «Семья Пирожковых» [30, с. 3-59] Веры Пановой и, наконец, ее знаменитая повесть «Спутники» - одно из первых произведений о Великой Отечественной войне, написанных по горячим следам событий (опубликована в 1946 г.).

В.В. Бианки писал из Осы 10 июня 1943 г.: «Вот мне надо работать, очень много работать: четыре книги для ДетГИЗа, две передачи в месяц для московского радио, очерки для ТАСС, рассказы для четырех журналов» [5, с. 25]. За 35 лет своей творческой деятельности Бианки создал более 300 рассказов, сказок, повестей, очерков и статей. В период своего «осинского сидения» было написано около двух десятков рассказов, среди них: «Приказ на снегу», «Тетерева в лунках», «Два белых, третий - как снег», «Поганки», «Мышарик», «Башенный стриж», «Рожденные радости», «Кто ночью не спит», «Глупые вопросы», «Тигр-пятиполосник» и другие.

Малоизвестный тогда писатель Геннадий Гор, переживший блокадную зиму 1941-1942 гг., написал в Перми (Молотове) 95 стихотворений в духе творчества «Объединения Реального Искусства» (ОБЭРИУ), куда в свое время входили Даниил Хармс, Александр Введенский, Николай Заболоцкий и другие. Эти стихи он никому не показывал, и никто не знал о его поэтических экспериментах. Они были опубликованы только в первом десятилетии XXI в. [12]. Впоследствии Геннадий Гор стал председателем Ленинградского отде- 
ления Союза советских писателей, а любителям фантастики он был хорошо известен, как чрезвычайно тонкий и сложный автор, пытающийся нащупать границы искусства и реальности - «магический реализм».

С января 1942 г. еженедельно по вторникам проводились творческие собрания писателей. За это время обсуждались произведения И. Луковского, Н. Касаткиной, С. Спасского, Н. Рыковой, Г. Семенова, В. Вальдман, А. Кулишер, В. Каверина, А. Первенцева и других [15]. Например, 21 ноября 1942 г. В.А. Каверин читал свои рассказы «Друг», «Любовь», «Русский мальчик», «Девушка на флоте», подвергшиеся тщательному анализу слушателей. Н.Я. Рыкова в связи с этим сказала: «В 1942 г. наметился в литературе правильный поворот, Каверин делает в прозе то, что Симонов - в поэзии. Литература там, где вечные темы: любовь, смерть, счастье» [6, с. 35]. В марте 1943 г. инженер завода имени Дзержинского И. Трайнин читал отрывки из своей повести «Мы еще встретимся» - о людях уральского военного завода. В обсуждении повести приняли участие писатели П. Ходченко, А. Льдов, Н. Арбенева [15]. В областной библиотеке на литературных вечерах выступали такие известные писатели, как А. Первенцев, А. НовиковПрибой, М. Слонимский, Л. Кассиль, В. Каверин, В. Панова и другие [28, с. 222-223].

Ушли на фронт, так и не написав свои, может, самые лучшие стихи пермские поэты В. Занадворов, А. Бычков, коми-пермяцкий поэт И. Гагарин. В годы войны писатели-пермяки в основном выпускали поэтические сборники. Это две книжки Б. Михайлова поэма «Ганя Опанасенко» и сборник «У Камы», «Снежный город» и «Стихи для детей» Е. Трутневой. А. Спешилов написал сборник рассказов о гражданской войне «Преданность». Борис Ширшов и Афанасий Матросов написали «Боевые частушки», выдержавшие два издания [24, с. 9].

Н. Степанов в статье «Молотовские писатели», опубликованной в начале 1942 г., так кратко охарактеризовал состояние литературы в Прикамье: «Объем продукции молотовских писателей невелик: два выпуска литературно-художественных сборников "Прикамье” (за 1940 и 1941 г.) и несколько небольших книжек прозы и стихов: А. Спешилова "Бурлаки", И. Трайнина “Там, где свирепствуют штормы”, Б. Михайлова “Июнь”, В. Занадворова “Простор”. 
Этот небольшой объем продукции свидетельствует о молодости молотовского литературного объединения, об отсутствии прочных литературных традиций. Молотовские писатели не являются какойлибо литературной “школой”, не претендуют на единство направления и стиля. Их больше всего сближает любовь к родному краю, к суровой и могучей природе севера, к его крепким мужественным людям» [31, с. 104].

Однако уже начиная с № 4 литературно-художественного сборника «Прикамье» (с № 5 он был переименован в альманах) стали публиковаться писатели не только пермские, но и столичные. Четыре номера этого альманаха вышли только в 1942 г., то есть он превратился в настоящий «толстый» литературный журнал с совсем не «провинциальным» художественным содержанием. В редколлегию альманаха вошли: В.А. Каверин, Б. Михайлов, М.Л. Слонимский, А.М. Семенов, С.Д. Спасский, Л.Н. Тынянов $[22$, ф. 105, оп. 9, д. 21, л. 148]. Более того, этот альманах стал издаваться в Перми, а не в Свердловске, как это было раньше. Расширились типографские возможности города в результате эвакуации Ленинградской типографии имени М. Горького (знаменитый «Печатный двор»): в Пермь (Молотов) приехали около 200 специалистов, были привезены шесть линотипов, четыре печатные машины и другое оборудование. На этой базе в 1942 г. создали книжную типографию № 2. Ленинградские мастера обучили своему делу молодых рабочих, воспитали в лучших традициях новое поколение полиграфистов [23, с. 169].

Директор Молотовского (Пермского) издательства А.Н. Спешилов не мог первоначально загрузить заказами такую огромную, по меркам г. Молотова (Перми), типографию. Однако он нашел остроумный выход из положения. Накопившиеся бумажные отходы: срыв, обрезь и прочее использовали для выпуска детских «книжек-малышек». Каждый месяц выпускали «книжки-раскладушки», и они расходились моментально [36, с. 157].

А.Н. Спешилов провел огромную работу по упорядочиванию деятельности издательства. В своем первом приказе после назначения директором он дает нелестную характеристику увиденному: «Помещение издательства захламлено разным мусором; рабочие столы имеют грязный, неряшливый вид. Не только под столами, но и на столах, на стенах, на шкафах пыль и грязь. На 
единственном окне в издательстве на вершок грязи. Архив издательства лежит беспорядочно кучей на шкафах. При входе в издательство в первую очередь бросается в глаза “обеденный” стол, на котором валяются разные хозяйственные предметы, не относящиеся к издательству» [11, ф.р-1196, оп. 2, д. 1, л. 1-1об.].

А.Н. Спешилов в целях «создания условий для бесперебойного и последовательного прохождения рукописей через редакционный портфель» расширил состав редакционного аппарата и редакционно-художественного совета за счет эвакуированных писателей [11, ф.p-1196, оп. 2, д. 1, л. 2]. С.Л. Рыков был назначен главным редактором, председателем редакционно-художественного совета, ответственным редактором альманаха «Прикамье». Ему разрешили «использовать для занятий любое время дня» $[11$, ф.p-1196, оп. 2, д. 1, л. 4]. Затем главным редактором стал опытный ленинградский журналист Алексей Михайлович Семенов, которого А.Н. Спешилов впоследствии очень лестно характеризовал: «Профессионально грамотный, с крепкой партийной закалкой, он был уважаемым человеком среди издателей и авторов. Семенов умел предупреждать все возможные ошибки в издательском деле. Являясь на работу, Алексей Михайлович всегда вежливо, на равных, здоровался с сотрудниками, молча садился за редакторский стол. Уходил с работы последним. Мы удивлялись, откуда у больного человека бралось столько сил и энергии» [36, с. 158]. Должность редактора художественной литературы заняла Н.Я. Рыкова, ей предписывалось: «К 1 апреля разобрать имеющиеся самотечные рукописи. Лучшие рекомендовать к печати, часть передать в отд. ССП, остальные, по своему усмотрению, возвратить авторам с краткими рецензиями» $[11$, ф.p-1196, оп. 2, д. 1, л. 2об.]. Всем работникам редакционного аппарата приказывали «обратить серьезное внимание на редакционную обработку и правку оригиналов для того, чтобы избежать излишних типографских расходов по правке гранок и связанной с этим задержкой книг в производстве. Расходы по правке готового набора, допущенные по вине редакционного аппарата, будут относить за счет виновных» [11, ф.р-1196, оп. 2, д. 1, л. 2].

По инициативе Молотовского издательства тематический план на 1942 г. был пересмотрен в сторону увеличения, и только 
27 апреля 1942 г. его утвердили издательским управлением ОГИЗа. Список партийно-массовой литературой был согласован с обкомом ВКП(б) [11, ф.p-1196, оп. 2, д. 1, л. 6].

С 16 ноября по 16 декабря 1942 г. «учитывая решение рабочих и служащих», Молотовское издательства включилось во фронтовой месячник помощи защитникам Сталинграда и Кавказа [11, ф.p-1196, оп. 2, д. 1, л. 14]. За этот месячник принимались обязательства перевыполнения плана. В частности, в этом плане был следующий пункт: «В течение фронтового месячника перейти на безграночную работу, как более экономную в смысле времени и расходования средств. Для обеспечения этого мероприятия Редакционному аппарату необходимо обратить внимание на улучшение технического качества рукописей» [11, ф.р-1196, оп. 2, д. 1, л. 14об.]. Однако обязательства выполнены не были. По мнению директора издательства: «Это объясняется тем, что некоторые работники издательства не мобилизовались на выполнение взятых обязательств и недооценили политическое и хозяйственное, а также оборонное значение фронтового месячника, работали без напряжения, обычными темпами» [11, ф.р-1196, оп. 2, д. 1, л. 15об.]. Вместо запланированных 1,5 авторских листа к сдаче в производство издательство сдавало ежедневно в среднем 1,3 авторских листа. Вместо 39 авторских листа было сдано 34, что составило 87 \% плана [11, ф.p-1196, оп. 2, д. 1, л. 15]. Производственный сектор «из-за нечеткой работы редакционного сектора, а также перенесения некоторых книг на 1943 год из-за нехватки бумаги» план месячника по выпуску книг выполнил лишь на 86 \% (план 46,55 авторских листа, вышло из печати 40,18 авторских листа) и не смог перейти на «безграночную работу» [11, ф.р-1196, оп. 2, д. 1, л. 15об.]. В целом план 1942 г. по названиям вышедших книг был выполнен на 96 \%, по объему - на 76 \%, по тиражам - на 97 \% [11, ф.p-1196, оп. 2, д. 1, л. 15об.].

Однако на самом деле число выпускаемых издательством книг резко возросло. Если в 1941 г. вышло 25 названий общим тиражом 100 тысяч экземпляров и объемом 60 учетно-издательских листов, то в 1942 г. - уже 50 книг объемом 100 учетно-издательских листов и тиражом 500 тысяч экземпляров. Число названий увеличилось вдвое, а тираж - в пять раз [1, с. 135]. Темп, набранный издательством, не снизился и с началом 1943 г. Так, с января 
по апрель издали еще 37 книг. А всего с июня 1941 г. по апрель 1943 г. -112 [22, ф. 105, оп. 9, д. 21, л. 149].

Книги, изданные в Молотовском издательстве, стали привлекать внимание и вызвали критику со стороны центральных литературных журналов. Так, объектом критики стало либретто оперы «Иван Грозный», написанное О.М. Бриком по заказу Большого театра и опубликованное в январе 1942 г. тиражом в 5000 экземпляров в Молотове (Перми) [8]. В октябрьском номере (№ 10) журнала «Октябрь», который являлся органом Союза советских писателей, была опубликована большая критическая статья Н. Семенова «Издательская ошибка (Об исторической трагедии О. Брика)». Автор считал, что ни истории, ни трагедии в этой книжке нет, а есть лишь хоры, арии и серенады. В газете «Литература и искусство» за несколько дней до опубликования постановления Совета Народных Комиссаров Союза ССР о присуждении Сталинских премий за выдающиеся работы в области искусства и литературы за 1942 г. появилась статья Д. Рабиновича о постановке оперы Мариана Коваля и пермского поэта В.В. Каменского «Емельян Пугачев» [15]. В этой статье Д. Рабинович утверждал, что успех музыки оперы «Пугачев» произошел «не только без помощи словесного текста, но сплошь и рядом вопреки ему» [15].

Начальник управления пропаганды и агитации ЦК ВКП(б) Г.Ф. Александров инициировал проверку печатной продукции, опубликованной Молотовским (Пермским) издательством. Результатом этой проверки стало его докладная секретарям ЦК ВКП(б) А.С. Щербакову, Г.М. Маленкову и А.А. Андрееву, в которой он в частности так охарактеризовал рассказ Л.Ю. Брик о В.В. Маяковском: «Рассказ Брик “Щен” посвящен щенку, которого выкормил Маяковский. В книге щенок сравнивается с Маяковским <...> Подобная пошлость занимает печатный лист и издана 15-тысячным тиражом (На самом деле пятитысячным - прим. авт.)» [10]. А по поводу исторической трагедии О.М. Брика «Иван Грозный» был сформулирован еще более жесткий пассаж: «Перед нами хладнокровная и сознательная халтура. Это дурная, скверная шутка, непростительная в то время, когда так вырастает чувство ответственности за каждую написанную строку» [28, с. 232-233]. Данная докладная и легла в основу постановления ЦК ВКП(б) «О работе Молотовского областного издательства» от 19 марта 1943 г. 
В постановлении ЦК ВКП(б) перечислялись «бессодержательные и никому не нужные книги» [21, с. 23]. К ним относились «совершенно ненужная книга» Юрия Широкого о цирковых артистах, дрессированных лошадях и львах и «бесполезная для медицинских работников и недоступная по своему содержанию для массового читателя» книга В.П. Первушина «Нервная система и ее заболевания» [21, с. 23-24]. В постановлении среди «бессодержательных» книг были отмечены «серые, недоработанные стихи» А. Бычкова «Железо и огонь» [9], «пошлые рассказы» Л.Ю. Брик о Маяковском «Щен», «фальшивая повесть» С. Розенфельда «Гунны» [32], «ненужная книга» С. Рыкова «Боги Олимпа. Мифы и сказания Древней Греции» [33], «недоработанная книга» В. Попова «По Каме в дни Отечественной войны» [25]. «Грубой политической ошибкой» в постановлении назвали «пьесу» (либретто оперы «Иван Грозный») О.М. Брика и исторические очерки И.Б. Берхина «Отечественная война 1812 года» [4]. По поводу «пьесы» О.М. Брика отмечалось: «В антихудожественной пьесе Брика грубо искажается образ Ивана Грозного. Иван Грозный как выдающийся государственный деятель в пьесе совершенно не показан» [21, с. 24]. Разгромную характеристику получили исторические очерки И.Б. Берхина: «Дается путанное изложение событий Отечественной войны 1812 года, принижается роль великого русского полководца Кутузова в разгроме армий Наполеона [21, с. 24]. Автор повторяет затасканную немецкими «историками» антирусскую концепцию, приписывающую Кутузову пассивную роль в ведении военных действий, изображающую дело так, якобы Кутузов рассчитывал уничтожить врага без крупных сражений, «надеясь на внутреннее разложение армии и уничтожение ее партизанскими отрядами» [21, с. 24].

20 апреля 1943 г. на заседании бюро Молотовского обкома ВКП(б) первым пунктом повестки дня был вопрос: «О работе Молотовского Областного Издательства ОГИЗа» [22, ф. 105, оп. 9, д. 21, л. 148]. Справку к заседанию бюро подготовила «бригада по обследованию Облиздательство» [22, ф. 105, оп. 9, д. 21, л. 148]. В этой справке отмечали, что писатели и издатели слабо связаны с фронтом, «высасывают из пальца» фронтовые произведения, в книгах много пессимизма, отчаяния, растерянности. Издаются и переиздаются никому не нужные книги [1, с. 138]. Дважды, на- 
пример, переиздавались книги по агротехнике, сахарной свеклы и кок-сагыза, хотя эти культуры в области не растут, а действительно нужных книг не хватает [1, с. 138-139]. Почти все книги внешне выглядят очень плохо. В издательстве царят хаос в хозяйственных вопросах. Совершенно не отвечает требованиям помещение небольшая комнатка на чердаке без телефона, где вместе с группой писателей занималось до 15 человек [1, с. 139].

В справке отмечалось также, что писатели слабо отображали Урал в своих произведениях и «прошли мимо его интересного прошлого и героического настоящего, а если и изображали его, то не всегда верно, не всегда с симпатией». В качестве примера «бригада по обследованию» обрушилась с критикой на книгу М.Л. Слонимского «Председатель горсовета» [34], изданную в начале 1943 г. и не попавшую в список «бессодержательных и никому не нужных книг» в постановлении ЦК ВКП(б). М.Л. Слонимский в этой книге дает абсолютно убийственную характеристику чиновничьей старой Перми (Молотову): «Богатырей Пермь не рожала. < ..> Пермь была тормозом и тюрьмой. $<\ldots>$ Даже тараканы в Перми были умней городских заправил. <..> Эти чиновники и в огне не сгорели, и в Каме не потонули. А главное - они были не способны поумнеть. <..> Чиновники здесь принадлежали скорей к мертвой природе, чем к живой. Пермь была самым чиновничьим городом из всех русских городов, и медведь в гербе Пермской губернии для Перми никак не годился. В гербе старой Перми естественней был бы таракан» [34, с. 36-37].

На заседании бюро Молотовского обкома ВКП(б) присутствовали в том числе уполномоченный КПК (Комиссия партийного контроля) при ЦК ВКП(б) по Молотовской области и представитель ЦК ВКП(б) В.И. Ратнер. Бюро обкома ВКП(б) отметило «совершенно неудовлетворительную работу издательства, руководство которого не справилось со своими задачами» [22, ф. 105, оп. 9, д. 21, л. 149]. Подчеркивалось, что директор издательства А.Н. Спешилов и главный редактор Рыков «были оторваны от политической и производственной жизни своей области, не привлекали к активной работе редакционный совет и совершенно не работали с авторским активом - писателями. <..> ...не имели твердой линии в выполнении издательских планов, некритически относились к рукописям, уступая нажиму отдельных авторов, стремившихся 
протащить в печать свои явно недоброкачественные произведения» [22, ф. 105, оп. 9, д. 21, л. 149]. Особо выделялось, помимо «неряшливости», «безграмотности», «ошибок» и «запущенности финансово-хозяйственной части, несвоевременного учета и отчетности», отсутствие в изданных книгах «уральской тематики» [22, ф. 105, оп. 9, д. 21, л. 149].

В постановляющей части было принято: 1) «Освободить т. Спешилова от работы директора издательства как не справившегося со своими задачами. Поручить отделу кадров обкома ВКП(б) подобрать кандидатуру директора издательства»; 2) «...пересмотреть тематический план издания литературы на 1943 год и представить его к 27.04.1943 г. на утверждение обкома ВКП(б) ...»; 3) «предложить издательству вовлечь в активную работу редакционный совет... <..> Установить тесную связь с областной организацией союза советских писателей...»; 4) «отделу пропаганды и агитации обкома ВКП(б) обеспечить систематическое руководство деятельностью издательства и особенно - тщательный предварительный контроль рукописей всей издаваемой продукции»; 5) «обязать Облисполком тов. Кочергина оказать помощь издательству в предоставлении необходимого помещения, в улучшении бытовых условий работников и принять меры к упорядочению финансового и хозяйственного состояния издательства» [22, ф. 105, оп. 9, д. 21, л. 150].

О том, что ЦК ВКП(б) и бюро обкома дали неудовлетворительную оценку работе Молотовского областного издательства и указали практические меры по улучшению работы издательства [15] публично было заявлено в день советской печати (5 мая 1943 г.) в областной газете «Звезда» в большой передовице «Печать советского государства» [15], в которой подчеркивалось: «В дни войны неизмеримо выросли запросы трудящихся и повысились требования советского читателя к художественной литературе. Следует отметить, однако, что Молотовское областное издательство не справилось со своими обязанностями по выпуску доброкачественной литературной продукции» [15].

Практические шаги, предпринятые партийным руководством области, по выполнению постановления ЦК ВКП(б) были чрезвычайно непоследовательны и «не имели твердой линии». Главный виновник «вредного» издательского бума А.Н. Спешилов получил 
партийный выговор и был отстранен от должности директора, но не от должности главного редактора издательства, то есть фактически оставался ответственным за выпуск всей печатной продукции. Более того, «директорское кресло» так никто и не занял в течение всего 1943 г. и лишь 1 января 1944 г. в должность директора вступила ответственный секретарь исполкома городского Совета - Людмила Сергеевна Римская, а сам «виновник» был насильно отправлен секретарем облисполкома Б.Н. Назаровским по путевке в дом отдыха «Красный Яр» [36, с. 167].

Не были наказаны и писатели не только «бессодержательных и никому не нужных книг», но и те, кто написали «вредные» с политической точки зрения книги. О.М. Брик вместе с женой Е.Г. Соколовой в январе 1943 г., получив разрешение Моссовета по ходатайству Гослитиздата, возвращаются в Москву [10]. В конце 1942 г. молодой кандидат исторических наук Илья Борисович Берхин, эвакуированный из Брянска в Молотов в 1941 г., вступает в ряды Рабоче-крестьянской Красной армии, демобилизовался он только в 1946 г. В Молотове (Перми) он опубликовал три исторические научно-популярные брошюры: в сентябре 1941 г. «Когда и как русский народ бил немецких захватчиков» [4] тиражом в 5000 экземпляров, в январе 1942 г. «Александр Невский» [2] (тираж 10000 экземпляров) и в августе 1942 г. «Отечественная война 1812 года» [3] (тираж 10000 экземпляров). После демобилизации работал в Институте истории АН СССР и преподавал в МГИМО, профессор, заслуженный деятель науки РСФСР.

Отдел пропаганды и агитации обкома ВКП(б) обеспечил «систематическое руководство» деятельностью издательства и «тщательный предварительный контроль» всех рукописей. И, как результат, деятельность Молотовского издательства была по сути парализована. Так, если до апреля 1943 г. было издано 37 публикаций, то всего за год только 42 названия [23, с. 413-414]. В 1944 г. вышло уже 40 названий, а в 1945 - 62, но план 1944 г. был выполнен всего на $56 \%$, а план 1945 - на $71 \%$ [1, с. 140].

Но недостаточно было просто не печатать писателей, необходимо было провести с ними воспитательную работу, и конференция, состоявшаяся в июне 1943 г. в Перми, посвященная теме «Настоящее и прошлое Урала в художественной литературе», оказалось важнейшей площадкой для обсуждения всегда актуального 
вопроса: «Что делать, с чего начать и о чем писать»? Цель конференции была сформулирована достаточно четко: «О роли и месте писателя Урала в дни Отечественной войны конференция должна сказать полным голосом. Ибо того, что делается нашими писателями, той продукции, какая ими выпущена, явно недостаточно, а качество ее далеко еще не столь высоко, чтобы можно было говорить об успешном овладении писателями своим родом оружия в борьбе против гитлеровской Германии» [15].

Уральская межобластная научно-литературная конференция открылась вечером 13 июня 1943 г. в зале Молотовского облисполкома. На конференцию прибыли писатели, ученые, собиратели фольклора, краеведы, художники, журналисты, представители партийных и областных организаций из Свердловска, Молотова, Челябинска [15]. Председателем оргкомитета был профессор Молотовского педагогического института Е.А. Боголюбов [15]. Председатель Молотовского облисполкома С.А. Кочергин приветствовал собравшихся от имени обкома ВКП(б) и облисполкома, обратив особое внимание «на то обстоятельство, что литература еще отстает от задач дня, от творческого взлета промышленного и в целом хозяйственного развития Урала» [15]. В областной библиотеке 14 июня 1943 г. открылись выставки, приуроченные к конференции: организованная Молотовской художественной галереей «Урал в изобразительном искусстве» и областной библиотекой - книжно-иллюстративная выставка «Настоящее и прошлое Урала» [15]. Конференция проходила с 13 по 19 июня 1943 г. На конференции выступили профессор Молотовского педагогического института Е.А. Боголюбов, секретарь Молотовского обкома ВКП(б) И.Т. Виноградов, лауреат Сталинской премии профессор В.В. Данилевский (Свердловск), собиратель народного творчества В.П. Бирюков (Шадринск), профессор К.Н. Державин, профессор С.Г. Лавров (Кудымкар), Л.П. Скорино (Свердловск), самый известный уральский писатель П.П. Бажов, А.С. Ладейщикова (Свердловск), К.В. Рождественская (Свердловск), В.А. Будрин (Молотов), профессор С.С. Мокульский, И.В. Карнаухова (Молотовская область), профессор С.С. Данилов (Молотов) и др. Однако журналист областной газеты «Звезда», освещавший эту конференцию, отметил: «Нужно заметить, однако, что в прениях мало политиче- 
ской заостренности, высказывались иногда недостаточно глубоко продуманные мысли...» [15].

На конференции была принята обширная резолюция, в которой отмечалось: «Весьма положительное явление рост за последнее время продукции уральских писателей и в количественном и в качественном отношениях, расширение тематики и сферы их творческих интересов, разнообразие жанров, в которых они работают, и явно определившийся интерес к работе над уральским материалом» [11, ф.р-1588, оп. 1, д. 595, л. 1]. Однако вместе с тем подчеркивалось: «Конференция считает нужным отметить, что в работе уральских писателей не изжиты до сих пор некоторые серьезные недостатки, тормозящие литературную жизнь Урала и не дающие ей возможности достичь того высокого идейно-политического и художественного уровня, которого требует неуклонно растущее значение Урала в жизни нашей страны и в Отечественной войне советского народа против фашизма» $[11$, ф.p-1588, оп. 1 , д. 595, л. 1-1об.].

Для устранения «недостатков писательской работы на Урале и обеспечения творческого роста художественной литературы Урала» собравшиеся на конференции считали необходимым «изжить отдельные проявления профессиональной демобилизованности» и «обратить внимание всех уральских писателей на необходимость более глубокого и серьезного изучения уральского материала, истории Урала, его славных боевых дел в прошлом и настоящем, его людей и его быта, его промышленности и его сельского хозяйства [11, ф.р-1588, оп. 1, д. 595, л. 1об.].

Конференция рекомендовала направить «научно-исследовательский интерес уральских литературоведов к литературной истории Урала» $[11$, ф.p-1588, оп. 1, д. 595, л. 2]. Издать книги об уральских писателях Ф.М. Решетникове, А.П. Бондине, П.П. Бажове, В.В. Каменском, а также осуществить академическое издание полного собрания сочинений Мамина-Сибиряка. Подготовить иллюстрированную хрестоматию «Урал в художественной литературе» для детей и юношества и «Литературный путеводитель по Уралу» [11, ф.р-1588, оп. 1, д. 595, л. 2об.].

В резолюции конференции подчеркивалось, что «издательская работа в области художественной литературы и литературоведения является одним из наиболее отсталых и неорганизованных 
участков культурного строительства уральских областей. Выпуск ряда художественно слабых книг и недоброкачественной литературы, в частности - молотовским издательством, отсутствие широко разработанных планов издания уральских классиков литературы и современных уральских писателей, слабость активной организующей работы издательств с авторами, крайняя медлительность в выпуске книг и журналов, - все эти недостатки в работе уральских издательств требуют скорейшего устранения, и в первую очередь в молотовском отделении ОГИЗа, наиболее отсталом в своей работе» $[11$, ф.p-1588, оп. 1, д. 595, л. 3]. Рекомендовалось создать газету «Литературный Урал», единый общеуральский литературно-художественный журнал, литературный альманах «Прикамье» реорганизовать в ежемесячный и т.д... [11, ф.p-1588, оп. 1, д. 595, л. 3об.].

Однако критическая составляющая резолюции была чрезвычайна корректная. В основном на конференции наметили основные направления публикационной деятельности на ближайшие годы, что было чрезвычайно важным для молодых областных издательств Урала. Резолюция конференции была доведена до сведения всех областных партийных и советских организаций Урала. В Молотовской, Свердловской, Челябинской, Оренбургской областях, а также в Башкирской АССР стали практиковать обсуждение литературных произведения на партийных собраниях различного уровня, а не только Союза писателей. Ужесточились требования к перестройке деятельности писателей в соответствии с условиями военного времени. И, как результат, сократилась публикационная активность областных издательств, особенно в отношении художественной литературы.

В 1944 г. из всего репертуара книг в Молотовской (Пермской) области было опубликовано только шесть художественных изданий: Дар Д. «Рассказы о боевых друзьях», Любимов Б. «Забойщик Павел Поджаров», Мамин-Сибиряк Д.Н. «Детские рассказы», Сигов И. роман «На старом Урале», Славин Л. «Уралец: рассказ» и номер седьмой литературно-художественного альманаха «Прикамье» [23, с. 414-415].

С отъездом эвакуированных писателей отпала актуальность тщательного контроля за художественным творчеством на местах. Из Молотовской (Пермской) области в конце 1943 г. выехали все 
московские писатели, а в феврале 1944 г. - ленинградские. Творчество ведущих советских писателей в связи с окончанием эвакуации стало предметом пристального внимания ЦК ВКП(б) уже в столичных городах Советского Союза.

2 декабря 1943 г. выходит постановление секретариата ЦК ВКП(б) «О контроле над литературно-художественными журналами», в котором отмечалось, что Управление пропаганды и агитации ЦК ВКП(б) и его отдел печати «плохо контролируют содержание журналов, особенно литературно-художественных», и в результате такого слабого контроля в журналы «проникли политические вредные и антихудожественные произведения». Контроль за журналами возлагался на конкретных работников Управления пропаганды и агитации ЦК ВКП(б) [27, с. 507]. Началась новая страница борьбы за идейно-художественное содержание советской литературы, апофеозом которой стало знаменитое постановление Оргбюро ЦК ВКП(б) «О журналах “Звезда” и “Ленинград”».

Таким образом, началом массовой идеологической кампании против художественной интеллигенции в послевоенный период можно считать постановления ЦК ВКП(б) «О работе Молотовского областного издательства» от 19 марта 1943 г., в котором публично подверглись критики «бессодержательные и никому не нужные книги», а также редакторы, допустившие «грубые политические ошибки», издав «вредные» художественные произведения. C позиции сегодняшнего дня содержательный смысл публичных обличений и критики давно уже потерян. Однако практика административного давления и гонений на писателей, поэтов и драматургов, обретших в военные годы неожиданную творческую свободу, стала традиционной и неизменной составляющей советской реальности.

\section{Список литературы и источников}

1. Аверина Н.Ф. История пермской книги: очерк. Пермь: Перм. кн. изд-во, 1989. С. 125.

2. Берхин И. Александр Невский. Молотов: ОГИЗ Молотовское областное изд-во, 1942. 52 с.

3. Берхин И. Отечественная война 1812 года. Молотов: ОГИЗ Молотовское обл. изд-во, 1942. 72 с. 
4. Берхин И.Б. Когда и как русский народ бил немецких захватчиков (Материал в помощь агитаторам пропагандистам). Молотов: МолотовГИЗ, 1941. 47 с.

5. Бианки Е.В., Русанов В.Н. Виталий Бианки в Прикамье. Оса: Росстани, 1993. 95 с.

6. Боброва Е.Е. «Города великого гонцы» в Прикамье. Из истории эвакуации 1941-1945 годов // История Петербурга. 2006. № 1. С. 34-35.

7. Брик Л.Ю. Щен. Молотов: Молотовгиз, 1942. 16 с.

8. Брик О.М. Иван Грозный. Историческая трагедия. Молотов: ОГИЗ Молотовское обл. изд-во, 1942. 70 с.

9. Бычков Ал. Железо и огонь. Молотов: ОГИЗ Молотовское обл. изд-во, 1942. $47 \mathrm{c}$.

10. Валюженич Анатолий Брики в эвакуации [Электронный pecypc] // Уральский рабочий. 2014. 29 мая. URL: https://uralskyrabochi.ru/news/item/7092 (дата обращения: 21.08.2019).

11. ГАПК. Ф.р. 1188. ОП. 1. Д. 1. Л. 1; Ф.р. 1588. Оп. 1. Д. 599. Л. 6.

12. Гор Геннадий Красная капля в снегу. Стихотворения 1942-1944. М.: Гилея, 2012. 184 с.

13. Гусаров Н. Секретарь Молотовского обкома ВКП(б) Руководить - это значит предвидеть // Партийное строительство. Журнал ЦК ВКП(б). 1943. № 7. С. 7-12.

14. Докладная записка управления пропаганды и агитации ЦК ВКП(б) секретарю ЦК ВКП(б) А.А. Жданову о неудовлетворительном состоянии журналов «Звезда» и «Ленинград». 7 августа 1946 г. // Власть и художественная интеллигенция. Документы ЦК РКП(б) - ВКП(б), ВЧК - ОГПУ - НКВД о культурной политике. 1917-1953 / сост. А. Артизов и О. Наумов. М.: Демократия, 1999. C. 559-565.

15. Звезда. Орган Молотовского областного и городского комитетов ВКП(б) и обл. Совета депутатов трудящихся. - 1943. № 71 (7061). - 30 марта; № 81 (7071) - 13 апреля; № 96 (7086). 5 мая; № 124 (7114). - 15 июня; № 126 (7116). - 16 июня.

16. История Урала. Пермь: Кн. изд-во, 1977. Т. 2. С. 489.

17. Кимерлинг А.С. Молотовское эхо идеологической кампании 1946 года: местная печать разоблачает М. Зощенко и А. Ахмато- 
ву // Вестник Пермского университета. История. 2013. Вып. 3 (23). C. $188-195$.

18. Маяковский В. Лозунги-рифмы. Молотов: ОГИЗ Молотовское обл. изд-во, 1941. 23 с.

19. Нечаев М.Г. Вклад Пермского края (Молотовской области) в победу в годы Великой Отечественной войны // Культурноисторическое наследие как фактор устойчивого развития территории: материалы Всероссийской научно-практической конференции с международным участием, 19-20 ноября 2015 года / Соликамский государственный педагогический институт (филиал) ФГБОУ ВО ПГНИУ; Г.А. Лебедева, В.В. Дементьева, составление. Соликамск: Изд-во СГПИ, 2015. С. 85-88.

20. Николаев С. Годы свершений. 1938-1988. Пермь, 1988. C. $20-21$.

21. Партийное строительство // Журнал ЦК ВКП(б). 1943. апрель. № 7. С. 23.

22. ПермГАСПИ. Ф. 105. ОП. 9. Д. 21. Л. 148.

23. Пермский край в Великой Отечественной войне / Энциклопедия: пилотный выпуск / авт.-сост. А.Г. Зебзеева, Т.И. Силина, Т.И. Демиденко, Н.А. Зенкова; науч. ред. В.П. Мохов. Пермь: Издво «Пушка», 2015. С. 95.

24. Писатели Пермской области: Биобиблиографический справочник / сост. А. Крашенников. Пермь: Перм. кн. изд-во, 1985. С. 9.

25. Попов В. По Каме в дни Отечественной войны. Молотов: ОГИЗ Молотовское обл. изд-во, 1942. 40 с.

26. Постановление Оргбюро ЦК ВКП(б) о журналах «Звезда» и «Ленинград». 14 августа 1946 г. // Власть и художественная интеллигенция. Документы ЦК РКП(б) - ВКП(б), ВЧК - ОГПУ - НКВД о культурной политике. 1917-1953 / сост. А. Артизов и О. Наумов. М.: Демократия, 1999. С. 587-591.

27. Постановление секретариата ЦК ВКП(б) «О контроле над литературно-художественными журналами». 2 декабря 1943 г. // Власть и художественная интеллигенция. Документы ЦК РКП(б) ВКП(б), ВЧК - ОГПУ - НКВД о культурной политике. 1917-1953 / под ред. акад. А.Н. Яковлева; сост. А. Артизов, О. Наумов. М.: МФД, 1999. С. 507.

28. Прикамье. Век XX: учеб. пособие. Пермь: Книжный мир, 1999. C. 222-223. 
29. Прикамье: литературно-художественный альманах. Молотов: ОГИЗ Молотов. обл. изд., 1942. № 5. С. 13-14.

30. Прикамье: литературно-художественный альманах. Молотов: ОГИЗ Молотов. обл. изд., 1945. № 8. С. 3-59.

31. Прикамье: литературно-художественный сборник. Молотовгиз, 1942. № 4. С. 3-10.

32. Розенфельд Семен Гунны. Молотов: ОГИЗ Молотовское обл. изд-во, 1942. $112 \mathrm{c.}$

33. Рыков С. Боги Олимпа. Мифы и сказания Древней Греции. Молотов: ОГИЗ Молотовское обл. изд-во, 1942. 36 с.

34. Слонимский Мих. Председатель горсовета. Молотов: ОГИЗ Молотовское обл. изд-во, 1943. 130 с.

35. Сперанский А.В. «К штыку приравняли перо»: взаимодействие властных структур и литераторов Урала в годы Великой Отечественной войны // Десятые Татищевские чтения: мат-лы всерос. науч.-практ. конф. (Екатеринбург, 20-21 ноября 2013 года). Екатеринбург: УМЦ УПИ, 2013. С. 308.

36. Спешилов А.Н. Страницы прожитого. Автобиографическая повесть. Пермь: Перм. кн. изд-во, 1979. С. 142. 